\title{
The Adaptive Capacity Index of Smallholder Farmers to Climate Related Shocks in Kinakomba Ward, Tana River County, Kenya
}

\author{
Peter Ndegwa* Andrew W. Wamukota Annie H. Ong'ayo \\ Department of Environmental Studies-Community Development, Pwani University, P. Box 195, Kilifi
}

\begin{abstract}
According to IPCC (2014) Adaptive capacity is the ability of systems, institutions, humans and other organisms to adjust to potential damage, take advantage of opportunities and respond to consequences arising. In a climate change context it relates to inter-relationship of social, political, economic, technological and institutional factors operating at a variety of scales Vincent, Katharine (2007) some genetic while others exposure specific. This study analyzed the adaptive capacity to climate related shocks of 390 farming households in Kinakomba Ward. The objective was: To determine the adaptive capacity index of the smallholder farmers in Kinakomba Ward. The index included five indicators of human resources, physical resources, financial resources, information and livelihoods diversity (Eakin and Bojorquez-Tapia 2008). The researcher used two methods to analyse adaptive capacity: Firstly an interview with 390 farming households to gather data on farming and household characteristics and Natural resources availability and secondly a panel of $15 \mathrm{Key}$ Informants provided ratings of indicators of adaptive capacity using analytic hierarchy process (AHP). Using the Analytic Hierarchy Process (AHP) the results indicated that Livelihoods Diversity had the highest adaptive capacity score at 0.3 while the lowest adaptive capacity for Criterion was information at 0.12 . Meaning that Livelihoods diversity was 3 times more preferred than information. The panel of key informants gave this alternative the highest weight and so this was the single adaptive capacity for Kinakomba ward. The results further revealed that occupational multiplicity had the highest score at 0.21 the panel of the key informants gave this indicator a high rating thus making it have the highest adaptive capacity while the lowest was given to infrastructure at 0.03 , meaning occupational multiplicity at 0.21 was 6 times more preferred to infrastructure at 0.03 . The study concluded that When the Number of livelihoods sources are many and when the number of members in the household are also having different sources of livelihoods, then that household has a high adaptive capacity. Consequently when all the members of the households are adults and each has a job then the adaptive capacity of that household is high while a high dependency ratio leads to low adaptive capacity. The study recommended that the County and National governments and stakeholders to employ measures to adapt to climate change and variability.
\end{abstract}

Keywords; Analytic Hierarchy process(AHP), Adaptive Capacity, Key informants, Analytical Network Process (ANP) software, Super Decisions version 3.0

DOI: $10.7176 /$ FSQM/95-07

Publication date:March $31^{\text {st }} 2020$

\section{Introduction}

The adaptation to climate change debate is driven by questions like what to adapt to, what or who adapts, how adaptation happens and to what extent. Climate change manifests in long-term trends in mean temperatures and other climatic norms, like precipitation, sea-level rise with particular implications for infrastructure planning, agriculture and human health, and extremes in variability that can trigger natural disasters such as drought, floods, hurricanes, fires and so on (IPCC 2007). Both short-term uncertainty in variability and extremes and long-term trends need to be considered (Adger and Brooks, 2003). In climate change literature, Stanton et al. (2008) observe the narrow framing used to approach decision making for climate change policy. Harvey (2010) argues that a new macro-economic vision is needed to help move past the internal contradiction of contemporary economics that promotes energy intensive growth and so accelerates climate change with consequent growth inhibiting outcomes. Human-centred analyses seek to identify the human and social characteristics that determine the capacity of communities to face a shock or stress (Adger et al. 2005).

The diversity of work examining processes of adaptation has benefited from several typologies of adaptive action. Carter et al. (1994) distinguished between autonomous (automatic, spontaneous or passive adaptations) that occur as part of the routine of a social system, and planned (strategic or active) adaptations. Smit et al. (2000) added that adaptations may occur unintentionally as an incidental outcome of other actions further emphasizing the importance of contextualizing assessments of adaptive capacity and action. Burton et al. (1993) distinguish adaptations that prevent loss, spread loss, change use or activity, change location or engage in restoration. Adaptation can be characterized according to the form of action like technological, behavioural, financial, institutional or informational or the actor of interest like individual, collection or the scale of the actor like local, national, international and social sector like government, civil society, private sector (Smit et al. 2000). The challenge is to provide guidance for policy makers on what might be achieved through adaptation to limit or avoid the dangerous impact of climate change as a parallel agenda to mitigation (Hulmes 2009). Established institutions 
may also fail in the face of climatic extremes. Defining the limits to adaptation is contingent upon the levels of risk associated with climate change that are socially acceptable (Adger et al. 2009). More contemporary evidence of the limits to adapt alongside climatic variability and extremes comes from the failure of coping and past rounds of adaptation made manifest by natural disasters from regional food security crises, to major droughts and floods, or local events such as flash floods, water logging and landslides that are local disasters (ISDR 2009). Disasters happen when socio-ecological systems coping capacities are overwhelmed (ISDR 2004). Information fails when early warning is not provided (IFRC 2005). Institutions fail to enable adaptation when those at risk cannot hold risk managers to account, and when information and resources cannot be used effectively or equitably (Wisner 2006). Then there is the speed of development and application of appropriate technological innovations depending with the actors.

\section{Adaptation and Governance}

On governance Ostrom (2005) discusses the behavior of social rule systems and the governance outcomes they produce. Sets of rules interact in complex patterns, and the addition or removal of a particular rule may affect the interactions of the rest of the set and thus the governance outcome (Cox 2011). According to Basurto et al. (2013) Theories of collective action and common-pool resources (CPRs) contribute to the understanding of processes and conditions facilitating the likelihood of local self-organization. In 2007, Ostrom proposed the underpinnings of a framework for the systematic study of the governance of complex SESs, (Basurto et al. 2013).

Governance systems are composed of multiple actors including public, private or civil society organisations held together through formal and informal institutions that reproduce the balance of power and direction of development pathways in society. The nested and overlapping quality of governance regimes provides opportunity for adaptations to spread horizontally and vertically through communication networks and also for the top-down support or dissemination of adaptive capacity and practices (Mark Pelling 2011). Building adaptive capacity has the potential to reduce vulnerability to climate impacts by supporting adaptive action (Smit and Wandel 2006) and contributing to system resilience by enabling adaptation and transformation (Marshall et al. 2012, Rickards and Howden 2012). Where progressive adaptation as transition challenges established practices, or those of other competing emergent adaptations, overlapping administrative responsibilities with internal interactions, alliances and linkages can generate resistance to change (Foxton 2007).

According to Armitage (2007) Adaptive capacity is the capability of a system to maintain essential attributes of its self-organizing structure, function and feedback mechanisms in response to disturbance. The capacity to adapt depends on the system properties which allow individuals or communities to adjust or recover from exogenous or endogenous perturbations in social or environmental conditions (Epstein 2014). Adaptation is about the processes individuals and groups select and implement adaptive choices and how these decisions are affected by resources, information, knowledge of the participants and relations with other formal and informal political processes as Adger et al. (2005) and Keskitalo et al. (2011) put it.

For smallholder farmers adaptive capacity is the "the ability of farmers to adjust to climate change, to temper and lessen potential damages, and to take advantage of opportunities or to cope with consequences" (IPCC 2001). Thus adaptive capacity refers to the ability of a human system to adjust to climate, to moderate potential damages and to take advantage of opportunities, or to cope with the consequences. The adaptive capacity inherent in a human system represents the set of resources available for adaptation (information, technology, economic resources, institutions), as well as the ability or capacity of that system to use the resources effectively in pursuit of adaptation (UKCIP 2003 and UNDP 2005). It is also a function of available financial resources, human resources and adaptation options. Adaptive capacity is a function of both asset based components of a community such as wealth and human capital (Moss et al. 2001) as well as less tangible aspects such as flexibility, innovation, redundancy, and perception of options (Yohe and Tol 2002, Marshall et al. 2010; Wongbusarakum and Loper 2011).

Adaptive capacity is the ability to design and implement effective adaptation strategies, or to react to evolving hazards and stresses so as to reduce the likelihood of the occurrence or the magnitude of harmful outcomes resulting from climate-related hazards. Adaptive capacities are seen as long-term measures which enable a society to change and transform current structures in order to live with environmental and societal changes in the long run without facing major harm, loss or damage. Components of adaptive capacities are linked to education and research capacities, gender equity, environmental status and ecosystem protection and investments Lavell et al. (2012) and Birkmann et al. (2010).

Coping capacities comprise all of the means available that may be relevant for minimizing damages during the occurrence of a hazardous event (Birkmann et al. 2011; Welle et al. 2012, 2013). The overall goal of coping is to ensure the functioning of a system and to maintain its structure as is in contrast to the notion of adaptation is linked to capacities to transform a system. Adaptation reduces impacts of climate related shocks and because it can lower vulnerability, and can increase resilience to climate change (ADB 2009). The enhancement of adaptive capacity is an effective means of facilitating adaptation to climate change and variability especially for vulnerable 
groups such as small-scale farmers in developing countries (IPCC 2001).

According to Epstein et al. (2014), adaptation depends on the human, physical and financial capital that groups possess and the way in which institutions and networks connect these resources to affected groups to encourage the choice and implementation of successful adaptive choices. These choices and the governance systems depend on the attributes of complex and dynamic social-ecological environment in which they operate (Acheson and Wilson 1996; Holling and Meffe 1996, Hovelsrud et al. 2010). The TEEB (The economics of ecosystems and biodiversity) project concluded that human activity had increasing negative effect on the planet's biodiversity and the robustness of the ecosystems and their capacity to adapt to change has been reduced (TEEB 2010). Westley et al. (2013) add that depending on the knowledge base and the time horizon, innovation and transformational approaches to management and governance of such systems could accelerate the exhaustion of resources or increase the resilience of the social-ecological system.

This approach by Epstein et al. (2014) is the culmination of many years of research that collectively moved the study of environmental governance from the pursuit of institutional panaceas to recognition that selfgovernance is possible and that successful environmental governance depends on the fit between institutions and the SES (Ostrom 2009). The action situation occupies a central position in the SES framework as a model of institutionally structured arenas of interdependent choice (McGinnis 2011) where individual choices are mediated by the institutional and broader social-ecological setting drive social -ecological outcomes (Ostrom 2009). The sustainability of SES depends on how individuals and groups confront a diverse social and ecological problems and devise an equally diverse set of institutional solutions to manage those problems given their unique circumstances (Ostrom 2013). Epstein et al. (2014) states that in order to understand outcomes in SESs, we must evaluate the process by which those outcomes arise.

Epstein et al. (2014) uses the SES framework and the concept of linked action situation to evaluate how attributes of a SES affect six key phases of the adaptive process which include i) identification, classification and recognition of problems, (ii) search and identification of potential adaptive strategies, (iii) ways in which those strategies are evaluated (iv) choice of adaptive strategy from amongst the set of identified alternatives, (v) implementation of chosen strategies and (iv) the extent to which the chosen strategies as implemented resolve the problems generated by a disturbance. The disturbance is an exogenous input with its characteristics and measures of duration, intensity, frequency, and severity (Schoon and Cox 2011) but it may also arise from processes occurring in the focal SES.

Once actors have identified a problem, searched for, evaluated, selected and implemented an adaptive choice, the question which remains is whether this process has resolved the problem it was meant to address, and contributed to successful adaptive outcomes (Young 2008; Cox 2012). Successful adaptation is defined and measured in many ways that generally compare the social and economic well-being of actors and the production of ecological goods and services prior to and after the onset of disturbance. According to Epstein et al. (2014) a successful outcome depends on how the selected adaptive choice fits the problems generated by the disturbance or if there exists a causal mechanism that links an implemented strategy to the successful result (Hedström and Ylikoski 2010), or draws upon empirical counterfactuals in a comparative or matching design (Shadish et al. 2002; Rubin 2005). Also affecting adaptive outcomes are those factors that do not directly relate to the resolution of a problem, but instead mediate its effects on the chosen measure of success (Epstein et al. 2014).

\subsection{Objectives for the Study}

The Objective of the Study was to determine the adaptive capacity index of the smallholder farmers in Kinakomba Ward. The study was also guided by the following null hypothesis: $\mathrm{H}_{01}$ the adaptive capacity of the smallholder farmers in Kinakomba Ward is not significantly related to the ownership and access to resources, information and technology, and ability to diversify livelihoods to cope with Climate-related stresses.

\section{Research Methodology}

\subsection{Research Design}

The study adopted a descriptive research design which allowed collecting data in order to answer questions on current status of the subjects of the study. It was used to collect information about people's attitudes, opinions or habits Kombo and Tromp, (2006). Kothari (2004) recommended descriptive design as it allows the researcher to describe, record, analyze and report conditions that exist or existed. Multi-stage random sampling procedure was used to sample 390 households from accessible population of 3,920 households who are subjected to climate change shocks in Kinakomba Ward. A sample size of $10 \%-30 \%$ of the accessible population is adequate to serve as a study sample (Mugenda and Mugenda 2005). First multi-stage random sampling was used to select Kinakomba Ward out of the fifteen administrative Wards in Tana River County. The selected Kinakomba Ward has five administrative Locations which are Gwano, Jamhuri, Kinakomba, Ndura and Mazuni. In the second stage the researcher selected eleven Sub-Location areas (ESLs) from each of the Locations. The ESLs that was Hara, Maroni and Wenje from Gwano Location, Bububu from Jamhuri Location, Majengo and Masalani from Kinakomba 
Location, Gafuru, Mazuni and Mkomani from Mazuni Location and Bondeni and Handampia from Ndura Location. Sample frame was obtained by listing the villages under each of the ESLs from where samples were taken. The strata was based on the smallholder farmers in the listed village. Stratified random sampling was used to sample households to participate in the study. The $10 \%$ of the households sampled was proportionately distributed in the strata and calculated as shown in Table 1.0.

Table 1.0 Sample Frame

\begin{tabular}{|l|l|l|}
\hline Location & Number of households & $10 \%$ of accessible \\
\hline Gwano & $\mathbf{9 5 2}$ & $\mathbf{9 5}$ \\
\hline Hara & 322 & 32 \\
\hline Maroni & 229 & 23 \\
\hline Wenje & 405 & 41 \\
\hline Jamhuri & $\mathbf{6 5 4}$ & $\mathbf{6 5}$ \\
\hline Bububu & 654 & 65 \\
\hline Kinakomba & $\mathbf{9 1 2}$ & $\mathbf{9 1}$ \\
\hline Majengo & 614 & 61 \\
\hline Masalani & 297 & 30 \\
\hline Mazuni & $\mathbf{5 4 2}$ & $\mathbf{5 4}$ \\
\hline Gafuru & 256 & 26 \\
\hline Mazuni & 128 & 13 \\
\hline Mkomani & 159 & 16 \\
\hline Ndura & $\mathbf{8 4 2}$ & $\mathbf{8 4}$ \\
\hline Bondeni & 492 & 49 \\
\hline Handampia & 352 & 35 \\
\hline Total & $\mathbf{3 , 9 0 2}$ & $\mathbf{3 8 9}$ \\
\hline
\end{tabular}

Households were selected by firstly using 10 landmarks i.e. Mosque, Church, Shop, school, Village water point, Posho mill, Village meeting baraza park, junction, electricity pole and Chief's camp and then from each point visiting households until 6 to 10 completed interviews were achieved. At the household level, the interview was with the head or spouse ensuring adequate representation of women.

The study took place in Kinakomba Ward, Galole Sub-County of Tana River County. Tana River County is subdivided into three Sub-Counties of Bura, Galole and Garsen with a total area of 35,375.8 KM² (13,658.7 sq. miles) whereby Trust land forms the bigger portion of the County with over $90 \%$ of the land. Galole Sub-County has four Wards of Wayu, Chewani, Mikinduni and Kinakomba. Kinakomba Ward is 556.9 square KM with 5 locations and 11 sub locations.

Kinakomba Ward has a population of about 18,000 people $(3908 \mathrm{HH})$ which is about $7 \%$ of the total population of the whole County. The Ward as a whole falls within the Coast low land climatic Zone $\mathrm{CL}_{3}, \mathrm{CL}_{4}$ and $\mathrm{CL}_{5}$. These zones are characterized by scarce rainfall ranging between $300 \mathrm{~m}-600 \mathrm{~mm}$ per annum only. The rainfall is erratic and unreliable resulting in persistent moisture stress in the soil profile. It is characterised by a flood plain along the banks of river Tana prone to flooding whenever the river bursts its banks. Apart from river floods the area is also sometimes affected by floods from the hinterland through seasonal rivers. The community lives in the floods plain and cultivate on the river banks making them very vulnerable to flash floods disasters because they have left the ground bare and the river banks are eroding at an alarming rate causing the river to change its course in many places frequently. The floods disasters experienced in Kinakomba Ward are on annual basis causing untold suffering, displacement of households and death of livestock. Being also in a Semi-Arid Area the community is confronted by immanent, persistent and prolonged droughts every second year and the frequency is increasing fast. The weather condition exhibits very high evaporation demand. From wood-head maps, the average evapo-transpiration during the dry and sunny months with a crop factor of 0.9 , is $5.2 \mathrm{~mm} /$ day CIDP II, (2018-2022). Average annual temperatures are about $30^{\circ} \mathrm{C}$ with the highest being $41^{\circ} \mathrm{C}$ around January-March and the lowest being $20.6^{\circ} \mathrm{C}$ around June-July.

The area is between $70-100 \mathrm{~m}$ above sea level. Slopes are within the range of $0.05 \%-0.15 \%$ with local surface undulations. The soils range from sandy, dark clay and sandy loam to alluvial deposits. The soils are deep around the riverine environments but highly susceptible to erosion by water and wind. Soils in the hinterlands are shallow and have undergone seasons of trampling by livestock, thus are easily eroded during rainy seasons CIDP II, (20182022). The vegetation ranges from scrubland to thorny thickets within the riverine area. Main crops grown are mangoes, bananas, maize, green grams, cowpeas, tomatoes, vegetables and melons while main livestock kept are cattle, sheep and goats. The study site is as shown in Figure 1 above. 


\subsection{Study area}

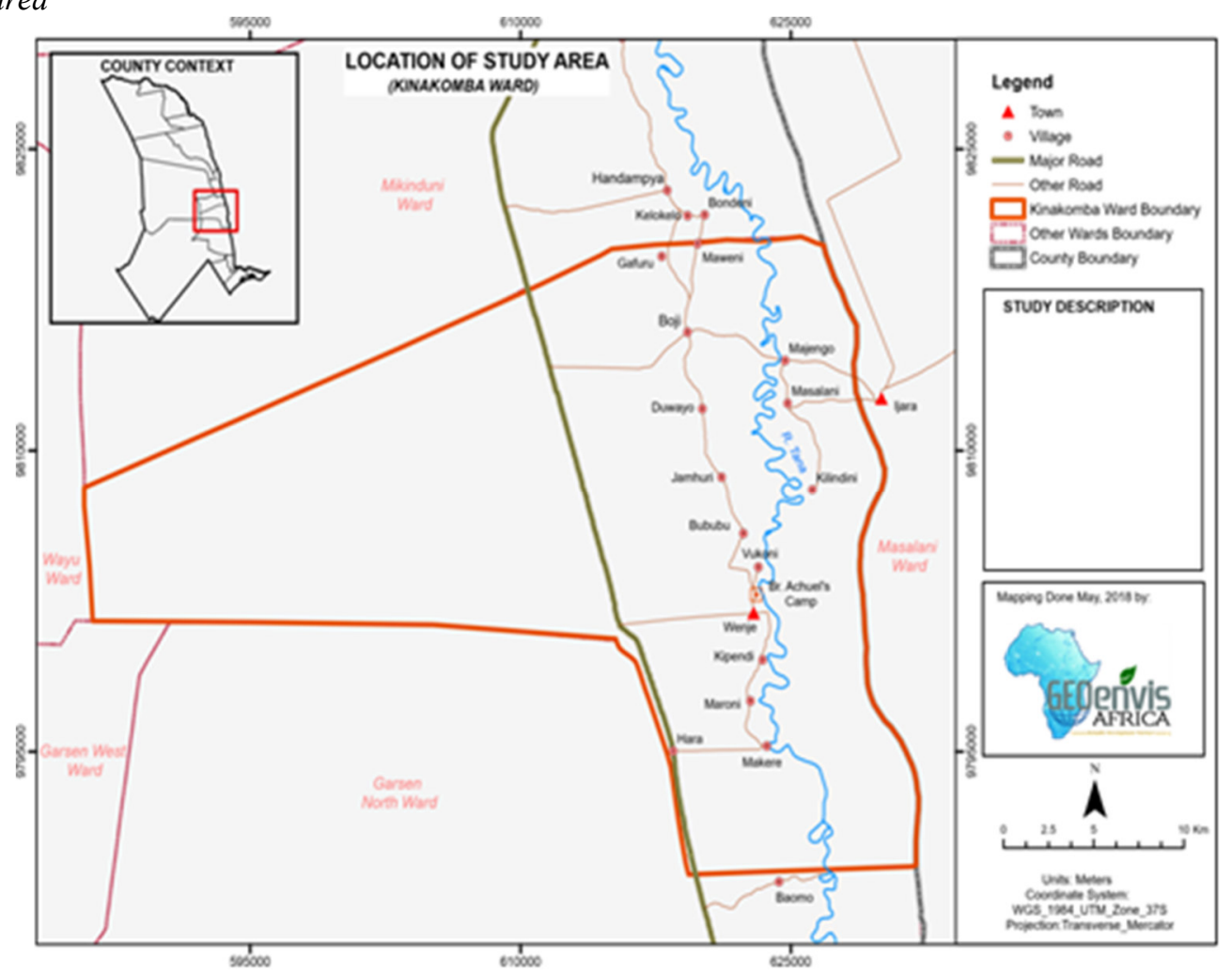

Figure 1 The map of Kinakomba Ward

\subsection{Data Collection Instruments}

\subsubsection{Questionnaire}

In this study, the researcher used questionnaires and an observation checklist to collect data. Three sets of questionnaires were developed and administered to the respondents. The researcher developed these questionnaires for the purpose of gathering information from respondents (Mugenda and Mugenda 2010). Observation overcomes one of the key disadvantages of interviews and questionnaires that is, that the responses provided may not be accurate (Dawson, 2009).The questionnaire for the smallholder farmers had two sections structured and semi structured all covering adaptive capacity.

Semi structured questions assisted in generating in-depth and explanatory qualitative information. This method allowed flexibility, follow up to original questions and pursuing of new lines of questioning, two-way interaction and facilitates exchange of information between the interviewer and interviewee making the atmosphere more relaxed. The use of both questionnaires and semi-structured questions is necessary in order to get as much information as possible from the community members. Administration of questionnaire to Key informants was done with people with vast experience and knowledge who can provide extensive insight into biosocio-cultural aspects of the community.

Focus Group Discussions was developed and used to collect information on Adaptive Capacity. The tool allowed for in-depth probing while the observation schedule was prepared and shared. This involved transect walks across the village and interacting with the villagers freely. This gave the feeling of the situation as is on the ground. For Adaptive Capacity analysis the researcher used two sets of respondents. One is a panel of fifteen key informants to provide ratings on the relative importance of the different indicators of adaptive capacity. The ratings were elicited using the pairwise comparison questionnaire, coming with the method of Analytic Hierarchy Process. These key informants ratings were used to generate the weights of each indicator using analytic hierarchy process (AHP) (Saaty 2008). The second set of respondents consisted of 390 farming households selected through proportionate random sampling. To form the adaptive capacity index a questionnaire was conducted on these respondents to gather data on farming and household characteristics using five indicators of adaptive capacity that is physical, financial, information, human and livelihood diversity.

\subsection{Validity and Reliability of Research Instruments}

The validation of the instruments were determined before being used for data collection in the field. This reduced biasness of the data collected (Abbott \& Bordens, 2011). This was done by experts from the department of 
Environmental Studies- Community Development of Pwani University, to assess the face, content and construct validity of the instrument. A pilot study was done prior to collection of data to test the reliability of the instruments .A test-retest technique was used to improve the questionnaire, semi-structured questions and focus group interviews. Piloting was carried out for 39 households which make 10 percent of the study sample. According to Orodho, (2004) the number in the pre-test should be at least 10 percent of the entire sample. Cronbach's alpha was used to determine the internal consistency of items in the questionnaire to gauge its reliability. According to Cronbach (1957) a coefficient of between $0.7 \leq \alpha<0.9$ is taken to be good while that of $\alpha \geq 0.9$ is taken to be excellent George, (2003).

\subsection{The Analytic Hierarchy Process (AHP)}

The second set of respondents for this study was a panel of fifteen key informants (drawn from the line ministries, involved in this area), purposively chosen, to provide ratings on the relative importance of the different indicators of adaptive capacity. The ratings were elicited using the pairwise comparison questionnaire, which comes with the method of Analytic Hierarchy Process. These key informants ratings were used to generate the weights of each indicator using analytic hierarchy process (AHP) (Saaty, 2008).

\section{Results and discussion on adaptive capacity}

The researcher sought to determine the adaptive capacity index of the smallholder farmers in Kinakomba Ward. There were two sets of respondents for this study. The first is the set of respondents which consisted of 390 farming households selected through proportionate random sampling. To form the adaptive capacity index a survey, with the aid of an interview guide, was conducted on these respondents to gather data on farming and household characteristics for the adaptive capacity indicators. Below are the Results from this survey.

\subsection{Number of Livelihoods or source of income in the household}

Majority $(67.7 \%)$ had two sources of income.

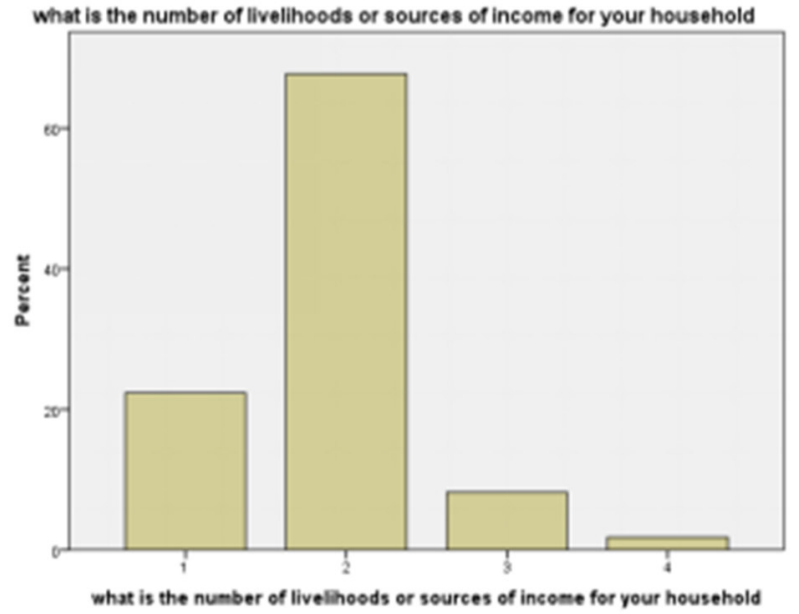

Figure 2 sources of income

Majority $(96.2 \%)$ had their first most important source of income being sale of crops. Meaning the respondents were mostly farmers. According to the Department for International Development (1992) "a livelihood is sustainable when it can cope with and recover from stresses and shocks and maintain or enhance its capabilities and assets both now and in the future, while not undermining the natural resource base". The farmers sale crops which they plant throughout the year and are able to sustain their livelihoods by coping with the stresses and shocks from climate shocks and enhance their capacities and build on the assets they have meaning they do not undermine the natural resources base for now nor in the future. Sale of crops which are grown throughout the year is a constant income that enables the farmer to plan for the next season what will be needed by the buyers and through this sustain a small but stable income.

The researcher asked the respondent how much they make from their first source of income and majority (78.2\%) make less than Kshs. 3,000. This is a small but stable income which enable a farmer to live within their means considering that this is after they have had their own food for the household and so it is the excess after the family has been fed. 
Table 2 Income from first source of income

\subsubsection{Income last month}

\begin{tabular}{|l|l|l|}
\hline & Frequency & Valid Percent \\
\hline Ks400 & 1 & 3 \\
Ks500 & 12 & 3.1 \\
Ks550 & 2 & .5 \\
Ks600 & $\beta$ & .8 \\
Ks650 & 1 & .3 \\
Valid & 2 & .5 \\
Ks700 & 153 & 39.2 \\
Ks1,2000 & 1 & 3 \\
Ks2,800 & 11 & 2.8 \\
Ks3,000 & 152 & 39.0 \\
Ks3,450 & 52 & 13.3 \\
Total & 390 & 100.0 \\
\hline
\end{tabular}

When asked the income for the last month majority (43.3\%) earned about Kshs. 2,000 while 34.6\% earned about Kshs. 1,700. The researcher asked the respondents out of the last month's income how much was spent and majority (40.3\%) spent Kshs.800 income from table below. This means they still remained with Kshs. 1,800 for other uses including emergencies in the family like sickness and school fees and in a rural setting this will ideally suffice since their basic needs especially when food has already been taken care of in crops they have harvested. These funds could also be used for savings in groups which have a big return at the end of a given period. Majority about $39.2 \%$ spend about Kshs. 800 per month during the dry season and majority $39.5 \%$ spend about Kshs. 1,500 during the wet season from the first most important source of income. The expenditure during the dry season was less because the farmers are using solar irrigation systems which are cheap to maintain and so they do not incur much expenses during the farming period. From focus group discussions the more expenses in the wet season is caused by the purchases of more pesticides and fungicides that come as a result of the rain seasons. This is also caused by the desilting which has to be done in the irrigation wells because the solar pumps are sensitive to silt, thus the farmers have to pay more for cleaning the wells more often like twice per month while in the dry season this is less. The river Tana is long and at this area it is old and very much silted so when it rains there are also floods which bring a lot of silt from upstream. The wet season also brings along other human diseases which call for medical care especially for the very young and the very old members of the family. From the second most important source of income majority 38.2\% spent about Kshs. 3,000 during the dry period and during the wet season majority $38.2 \%$ spent about Kshs. 500 .

Table 3 Expenditure of last month

\begin{tabular}{|l|l|l|}
\hline & Frequency & Valid Percent \\
\hline Ks180 & 1 & 3 \\
Ks270 & 1 & 3 \\
Ks300 & 2 & .5 \\
Ks400 & 1 & 3 \\
Ks450 & 1 & .3 \\
Ks500 & 1 & 3 \\
Ks600 & 3 & -8 \\
Ks700 & 3 & -8 \\
Ks780 & 1 & 3 \\
Ks800 & 157 & 40.3 \\
Ks900 & 2 & 5 \\
Ks1,800 & 11 & 2.8 \\
Ks2,000 & 52 & 13.3 \\
Ks2,100 & 153 & 39.2 \\
Ks4,500 & 1 & 3 \\
Total & 390 & 100.0 \\
\hline
\end{tabular}

\subsubsection{Income spent on food}

The researcher asked the respondents how much they spent on food during the last month and majority $38.2 \%$ 
spent about Kshs. 400. Considering that a family earns Kshs. 2000 in a month and spent only Kshs. 400 on food and has a balance of Kshs. 1,600 which is $80 \%$ of the income that family is doing well. This is because most of the food needs have been taken care of by the crops harvested and so the family has more money for other uses in the households. The money used for food supplements things like salt that have to be bought from the shops and cooking oil and others not found in the farm. Food security at the household level is the basis of a sustainable livelihood since can cope with and recover from immediate stresses and shocks in the surroundings. This also enables the head of the household to concentrate on other issues that bring about improvement of the family welfare. The household with enough food can maintain and enhance its capabilities and assets both now and in the future, while not undermining the natural resource base Department for International Development (1992).

Table 4 Expenditure on food last month

\begin{tabular}{|l|l|l|}
\hline & Frequency & Percent \\
\hline Ks400 & 149 & 38.2 \\
Ks1,400 & 51 & 13.1 \\
Ks1,500 & 1 & 3 \\
Ks1,800 & 2 & 5 \\
Ks2,000 & 2 & 5 \\
Ks2,100 & 11 & 2.8 \\
Ks2,200 & 16 & 4.1 \\
Ks2,300 & 23 & 5.9 \\
Ks2,400 & 81 & 20.8 \\
Ks2,580 & 11 & 2.8 \\
Ks2,700 & 27 & 6.9 \\
Ks2,800 & 10 & 2.6 \\
Ks3,000 & 5 & 1.3 \\
Ks4,000 & 1 & 3 \\
Total & 390 & 100.0 \\
\hline
\end{tabular}

\subsubsection{What is your other major expenditure?}

When asked the other major expenditure majority (90.3\%) spent the income on paying for school fees as Figure 3 indicates. And majority 46.7\% spent about Kshs. 650 monthly paying school fees. The school fees is more because most households have more than two children in school and the money needed can be divided on a monthly basis so that at the end of the term all the school fees has been paid. Also medication is another basic need in the family and has an expenditure which is high. These two school fees and medical fees are very important in a family and must be sorted for the family to have peace of mind. If a household can sort these two consistently that family has some stability and sustainability at the household level again keeping in mind that food has already been taken care of by the crops harvested from the farm.

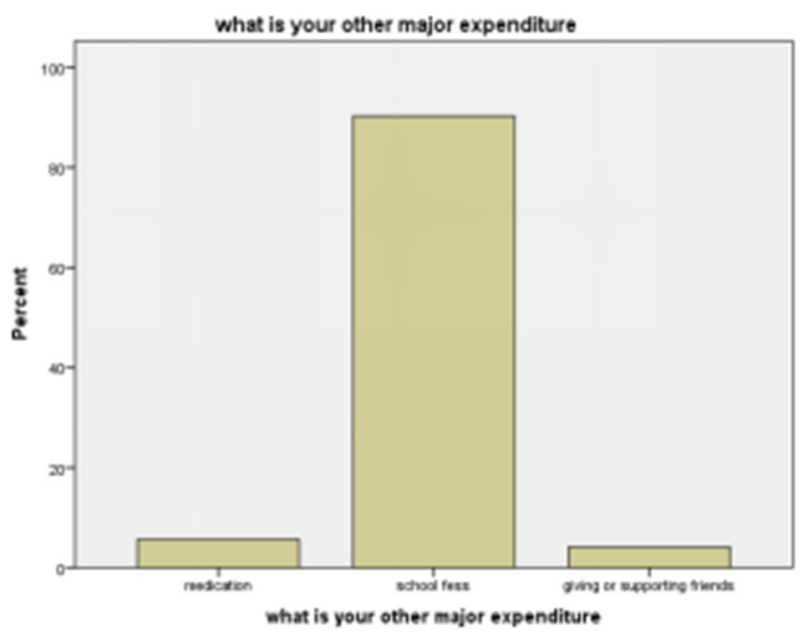

Figure 3 other expenditures

3.1.4 The amount of land owned

The researcher asked the respondents how much land they owned and majority (80.2\%) own 1.5 acres and below. And $99.7 \%$ of the respondents do not have ownership documents of the land they claim to own. Land is still not 
demarcated in the area and is still registered as community land by the government. So ownership is not felt by the members individually and this serves as a discouragement to the farmers because they cannot use it as collateral for getting loans from the banks and cannot sell it to earn any income. The land along the river is considered clan land since it has been owned by those clans for ages and only they have claim over it. So the clan subdivides that land to the family members in the clan and the members use such land as theirs. These are the pieces of land that are now owned by the households but the households do not have absolute ownership because being members of a clan there are rules that guide the use of such land. This is especially so because the land is along the river and fruits like mango trees thrive well along the river bank and then bananas and other fruits. The land is in a floods plain and so not very good for subsistent crops because when floods come all are swept away by the floods and these are flash floods which are erratic and unpredictable because they do not depend in the area, water from upstream which comes when there is a lot of rains upstream and when the mega dams that produce $80 \%$ of the electricity in the Country are released when they get full.

Table 5 Land owned by the respondents

\subsubsection{Percentage of land owned not devoted to crop production}

\begin{tabular}{|ll|l|l|}
\hline & & Frequency & Percent \\
\hline & 0.5 & 1 & 3 \\
1.2 & 167 & 42.8 \\
& 1.5 & 146 & 37.4 \\
Valid & 2 & 19 & 4.9 \\
& 2.5 & 41 & 10.5 \\
& 3 & 6 & 1.5 \\
4 & 10 & 2.6 \\
& Total & 390 & 100.0 \\
\hline
\end{tabular}

Majority $(51.3 \%)$ of land owned by the respondents is not devoted to crop production shown in Figure 4 . Most of the land owned by the community is in the floods plain. In this plain frequent floods sweeps away all the crops planted on it so farmers are afraid to put all their crop in their floods plain farms. Instead they have now opened land in the hinterland where they use solar irrigation pumping. This new land has expanded their land sizes and given them new opportunities where they can produce food throughout the year cheaply and without fear of the coming floods nor the frequent crocodile attacks that have been a major problem to the farmers. Majority $73.6 \%$ of the respondents planted at least eight different types of crops in their farms per year meaning they have a variety that can address different needs in their households as Table 6 shows. The ability to plant these number of crops was facilitated by the solar irrigation which provided water throughout the year. A farmer can now rotate different crops after every three months meaning they can now harvest four times a year different kinds of crops. So the land in the floods plain is losing meaning though since the community used floods receded irrigation type of farming since time in memorial which has severely been disrupted by climate change now they have adapted to the new irrigation methods that have enabled them to have sustainable food production systems.

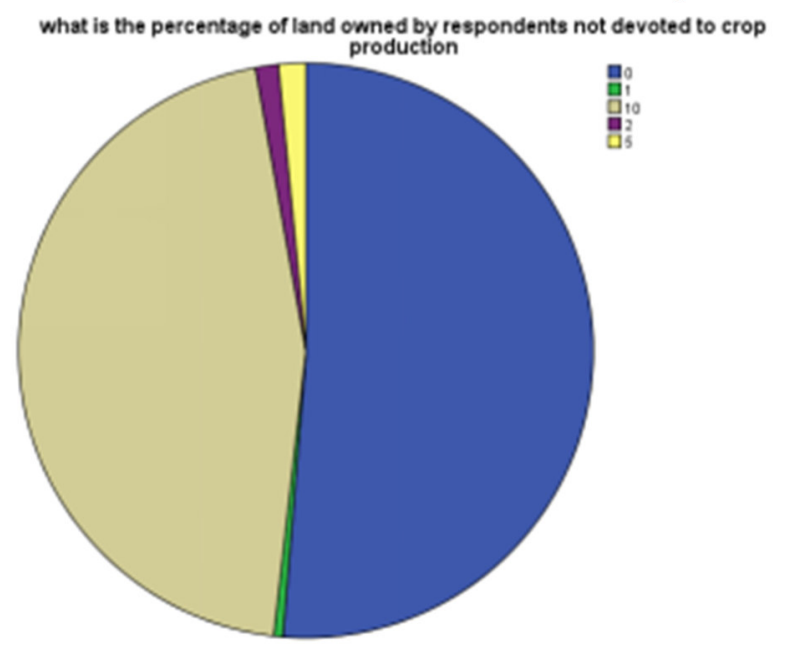

Figure 4 Percentage of land owned by respondents not devoted to crop production On the total number of types of crops planted by the respondents 
Table 6 Total number of types of crops planted in the farms

\begin{tabular}{|ll|l|l|}
\hline & & Frequency & Valid Percent \\
\hline & 2 & 4 & 1.0 \\
3 & 97 & 24.9 \\
Valid & 5 & 1 & 3 \\
& 6 & 1 & 3 \\
& 8 & 287 & 73.6 \\
& Total & 390 & 100.0 \\
\hline
\end{tabular}

3.1.6 Services of Facilities Index (SUM all present) within a radius of $20 \mathrm{Kms}$

The researcher asked respondents on the availability of essential services and facilities that were found within 20 Kilometres radius and majority $(99.7 \%)$ as shown in the Table 7 below had only 12 out of the 33 essential services or facilities available to them. This means the single Index is 0.3636 and to the two decimal points it is 0.4 indicating low adaptive capacity.

Table 7 Services or facilities Index (SUM all present) within a radius of 20 Kilometres

\subsubsection{Coping Strategy in the last 30 days}

\begin{tabular}{|ll|l|l|}
\hline & & Frequency & Percent \\
\hline \multirow{4}{*}{ Valid } & 12 & 1 & 3 \\
& 389 & 99.7 \\
& Total & 390 & 100.0 \\
\hline
\end{tabular}

The researcher wanted to know the coping strategies of the respondents for the last 30 days and majority $(60.2 \%)$ reduced the number of meals in order to cope as shown in figure 35 . Majority $60.2 \%$ sent children to sleep early between one and two days a week in order to cope. And majority 39.8\% never took their children out of school to cope with difficulties. Majority 39.8\% seldom sold their productive animals in order to cope with difficulties. Majority $60.2 \%$ went into debt between and two days a week in order to cope with difficulties during the month.

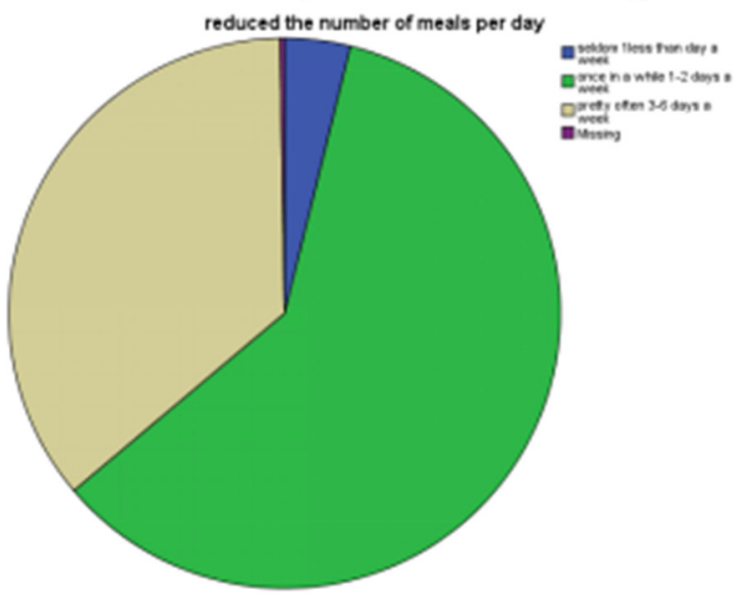

Figure 5 Reduced number of meals

3.1.8 Number of years spent in farming

The researcher asked the respondents about their age and majority $(60.2 \%)$ were of the age of 40 years and below. Majority of the respondents $72.8 \%$ have spent between 5 and 10 years doing farming as shown in the figure below Table 8 Number of years spent farming

\begin{tabular}{|ll|l|l|}
\hline Years & & Frequency & Valid Percent \\
\hline \multirow{6}{*}{ Valid } & less than 5 & 1 & 3 \\
& $5-10 \mathrm{yrs}$ & 283 & 72.8 \\
& $11-20 \mathrm{yrs}$ & 77 & 19.8 \\
& $21-40 \mathrm{yrs}$ & 26 & 6.7 \\
& above 41 & $\beta$ & 5 \\
& Total & $\mathbf{\beta} 90$ & 100.0 \\
& & & \\
\hline
\end{tabular}

The researcher asked the respondents the highest level of education attained and majority (64.9\%) had attained primary school level of education meaning majority are lowly educated.

Majority $62.9 \%$ have land measuring 1.5 acres as figure 6 shows 


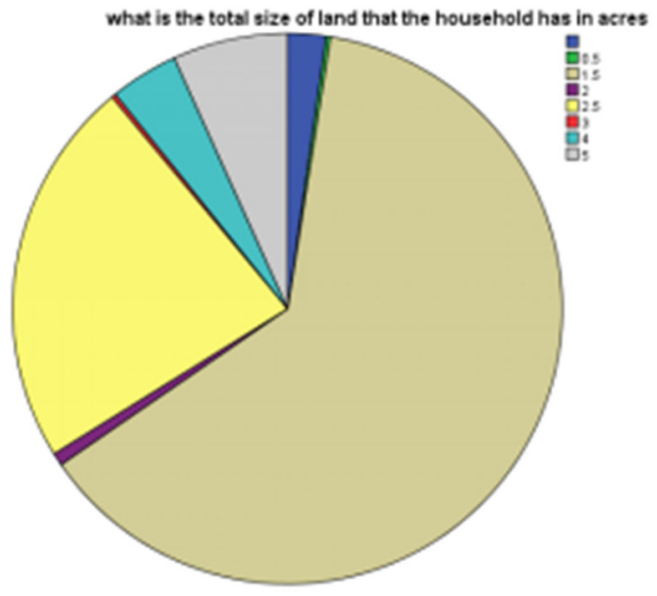

Figure 6 total size of land per household

\subsubsection{Method of water extraction}

The researcher asked the respondent what method of water extraction they have and majority $(88.7 \%)$ indicated as shown in Table 9 that they use solar energy meaning they use clean energy and sustainable methods of irrigation. But the respondents do not own any useful farm machine as indicated in Table 10

Table 9 Methods of water extraction from the river

\begin{tabular}{|ll|l|l|}
\hline & & Frequency & Percent \\
\hline \multirow{3}{*}{ Valid } & fossil fuel & 44 & 11.3 \\
& solar energy & 346 & 88.7 \\
& Total & 390 & 100.0 \\
\hline
\end{tabular}

On owning any useful farm machines majority (97.9\%) own none only $2.1 \%$ own water pumps

Table 10 Owning any useful farm machines

\begin{tabular}{|ll|l|l|}
\hline & & Frequency & Percent \\
\hline \multirow{3}{*}{ Valid } & water pump & 8 & 2.1 \\
& none & 382 & 97.9 \\
& Total & 390 & 100.0 \\
& & & \\
\hline
\end{tabular}

Majority (88.7\%) cultivated Maize, green grams, tomatoes, kales, cow peas, mangoes, bananas, lemon, onion, sweet potatoes and amaranth. This indicates the community has a variety of crops which can meet their nutritional needs if put to proper use. Majority $(90.8 \%)$ indicated that in the last one year the access to productive land for planting crops increased.

Table 11 Access to productive land in the last 12 months

\begin{tabular}{|l|l|l|}
\hline & Frequency & Percent \\
\hline increased & 354 & 90.8 \\
decreased & 35 & 9.0 \\
stayed the same & 1 & 3 \\
Total & 390 & 100.0 \\
\hline
\end{tabular}

When asked the reasons for increased access to productive crop land majority $(90.5 \%)$ said it was irrigation as shown in Figure 7. This means because of having water for irrigation from the solar pumping the residents of Kinakomba Ward were able to increase their land for crop production since there was water available. 


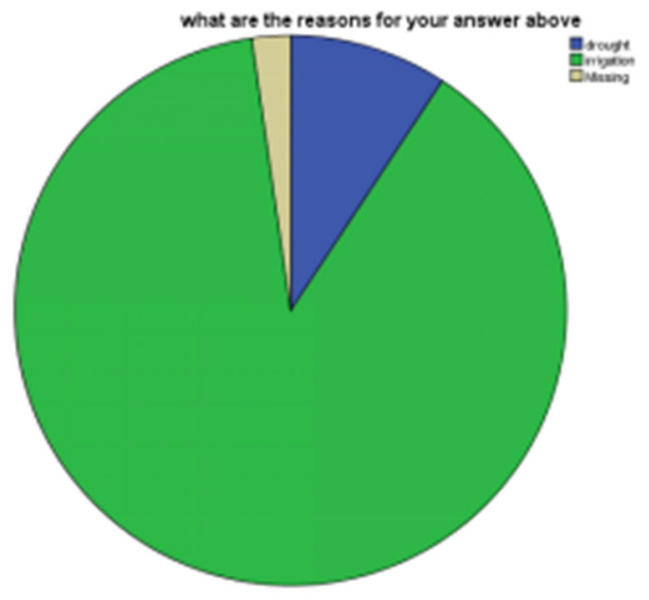

Figure 7 Reasons for increased land for crop production

Majority (97.7\%) admitted that their rain fed crops became more vulnerable to drought during the last one year.

Table 12 Rain fed crops are more vulnerable

\begin{tabular}{|ll|l|l|}
\hline & & Frequency & Valid Percent \\
\hline Valid & more vulnerable & $\beta 90$ & 100.0 \\
Missing & System & 9 & \\
Total & & 399 & \\
\hline
\end{tabular}

Majority (97.7\%) of the respondent said the main reason for failure of rain fed crops was drought. 3.1.10 State of livestock

Majority (37.4\%) said their livestock increased during the last one year as shown in Figure 8 and $37.2 \%$ said their livestock decreased. This is very close with a difference of only $0.2 \% .24 .4 \%$ said their livestock remained the same for the entire year.

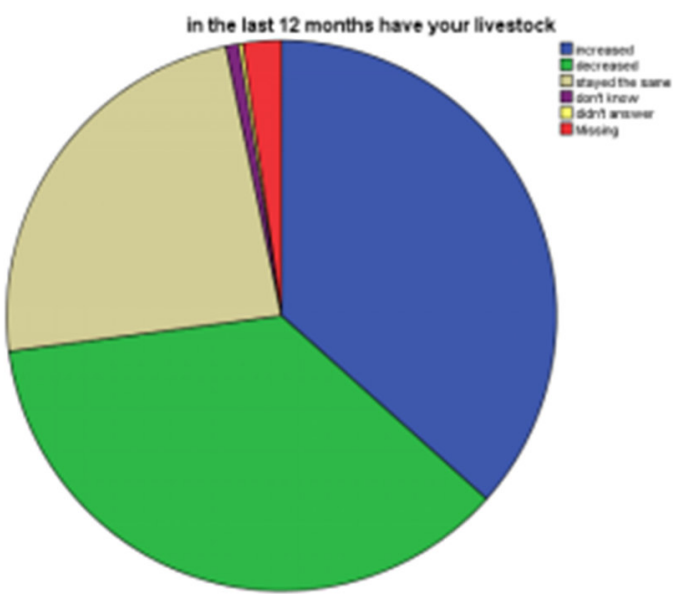

Figure 8 State of livestock in Kinakomba Ward

When asked to explain their answers for why their livestock were in that state majority $(57.7 \%)$ said because of better livestock health services and the second reason with $31.5 \%$ was given as drought meaning drought contributed negatively to the state of livestock in Kinakomba Ward. On how far the respondents walk their livestock to the nearest watering point majority $86.7 \%$ said it was between 100 and 500 metres. When asked the total value of the animals owned by the household's majority $40 \%$ said they owned Kshs. 0 but $14.4 \%$ gave a value of Kshs. 30,000

\subsubsection{Source of Credit}

Majority (86.9\%) admitted they know a source of credit as figure 9 shows. On further interrogation if they have availed of any credit to finance their farming activities from the year 2013 to 2017 majority $70.5 \%$ said no while $29.5 \%$ admitted they have accessed credit to finance their farming activities in the last five years. On remittance from family members $82.6 \%$ said they do not have access to that and only $17.4 \%$ said they have. 
Table 13 Source of credit knowledge

\begin{tabular}{|l|l|l|}
\hline & Frequency & Percent \\
\hline yes & 339 & 86.9 \\
no & 51 & 13.1 \\
Total & $\beta 90$ & 100.0 \\
\hline
\end{tabular}

\subsubsection{Training on Farming techniques}

Majority $(88.5 \%)$ said they have received trainings on different methods of farming in the last five years from 2013 to 2017. The trainings received included agroecology, soil building, water harvesting, food forest, farm design and integrated pest management. Majority (97.4\%) admitted they had consulted an agricultural extension Officer during the period of the last five years from 2013 to 2017.

Majority (95.9\%) agreed that they are members of a farming group.

Table 14 Membership of groups to farming households

\begin{tabular}{|l|l|l|}
\hline & Frequency & Percent \\
\hline yes & 374 & 95.9 \\
no & 16 & 4.1 \\
Total & 390 & 100.0 \\
\hline
\end{tabular}

\subsection{Results from the Analytic Hierarchy Process (AHP)}

The second set of respondents for this study was a panel of fifteen key informants (drawn from the line ministries, involved in this area), purposively chosen, to provide ratings on the relative importance of the different indicators of adaptive capacity. The ratings were elicited using the pairwise comparison questionnaire, which comes with the method of Analytic Hierarchy Process. These key informants ratings were used to generate the weights of each indicator using analytic hierarchy process (AHP) (Saaty 2008).

Method of Analysis

The adaptive capacity to climate change and variability of farming households was measured using a composite index. The index consisted of various indicators of adaptive capacity. Based on this approach, adaptive capacity was determined by ownership and access to resources, information and technology, and ability to diversify livelihoods to cope with Climate-related stresses. The adaptive capacity index in this study followed the variables included in the vulnerability index of Eakin and Bojorquez-Tapia, (2009). Each farming household was analyzed using five indicators of adaptive capacity that is physical, financial, information, human and livelihood diversity in the questionnaire.

Index Construction

The composite index was constructed and came up with adaptive capacity scores for each household. The first step was the scoring of categorical data using Analytic Hierarchy Process (AHP) based on the ratings/judgements of key informant. The Analytic hierarchy process is a multiple criteria decision-making tool introduced by Thomas Saaty (1980) that uses an Eigenvalue Betteridge, (1965) approach to the pair-wise comparisons. Following the AHP procedure, the components, indicators, and sub-indicators of adaptive capacity were turned into a multi-level hierarchical structure to facilitate pairwise comparisons using key informant judgment at each level. The instrument for the pairwise comparisons used AHP's 9-point scale format (Table 15) wherein the relative importance of indicators and sub-indicators were compared and assessed based on key informant's ratings.

Table 15 AHP 9-points scale format ratings for the alternatives

\begin{tabular}{|c|c|c|c|c|c|c|c|c|c|}
\hline & $\mathrm{AC}$ & 1 & 2 & 3 & 4 & 5 & 6 & 7 & 8 \\
\hline 1 & Causal Agent & 1 & 1 & 1 & 1 & 1 & 1 & 1 & 1 \\
\hline 2 & Capacity to Anticipate & 0.5 & 1 & 2 & 2 & 5 & 2 & 7 & 2 \\
\hline 3 & Occupational Mobility & 0.333 & 0.667 & 1 & 3 & 3 & 3 & 7 & 3 \\
\hline 4 & $\begin{array}{l}\text { Occupational Multiplicity(how many } \\
\text { work/employed) }\end{array}$ & 0.25 & 0.5 & 0.75 & 1 & 5 & 6 & 7 & 8 \\
\hline 5 & Social Capital(No. of group) & 0.2 & 0.40 & 0.60 & 0.80 & 1 & 5 & 5 & 5 \\
\hline 6 & Material Assets possessed & 0.167 & 0.333 & 0.50 & 0.667 & 0.833 & 1 & 7 & 8 \\
\hline 7 & $\begin{array}{l}\text { Technology-diversity of farming } \\
\text { methods used }\end{array}$ & 0.143 & 0.286 & 0.429 & 0.571 & 0.714 & 0.857 & 1 & 8 \\
\hline 8 & $\begin{array}{l}\begin{array}{l}\text { Infrastructure- } \begin{array}{l}\text { roads } \\
\text { education, transport, } \\
\text { telephone, security, banks }\end{array} \\
\text { electricity, }\end{array} \\
\end{array}$ & 0.125 & 0.25 & 0.375 & 0.50 & 0.625 & 0.75 & 0.875 & 1 \\
\hline & Columns Total & 2.718 & 4.436 & 6.654 & 9.538 & 17.172 & 19.607 & 35.875 & 36 \\
\hline
\end{tabular}


Step 1: Synthensizing Judgement

The researcher summed the values in each column of the pairwise comparison matrix.

Column Totals= (1)2.718, (2)4.436, (3)6.654, (4)9.538, (5)17.172, (6)19.607, (7)35.875, (8) 36

Step 2

The researcher divided each element of the matrix by its column total.

All columns in the normalized pairwise comparison matrix now have a sum of 1 . The resulting

Matrix is referred to as the normalized pairwise comparison matrix Table 16

Table 16 Normalised pairwise comparison matrix

\begin{tabular}{|c|c|c|c|c|c|c|c|c|c|c|}
\hline & $\mathrm{AC}$ & 1 & 2 & 3 & 4 & 5 & 6 & 7 & 8 & $\begin{array}{l}\text { Row } \\
\text { Average }\end{array}$ \\
\hline 1 & Causal Agent & 0.368 & 0.225 & 0.150 & 0.105 & 0.058 & 0.051 & 0.028 & 0.028 & 0.127 \\
\hline 2 & Capacity to Anticipate & 0.184 & 0.225 & 0.3 & 0.21 & 0.291 & 0.102 & 0.195 & 0.056 & 0.195 \\
\hline 3 & Occupational Mobility & 0.123 & 0.150 & 0.150 & 0.315 & 0.175 & 0.153 & 0.195 & 0.083 & 0.168 \\
\hline 4 & $\begin{array}{l}\text { Occupational } \\
\text { Multiplicity(how many } \\
\text { work/employed) }\end{array}$ & 0.092 & 0.113 & 0.113 & 0.105 & 0.291 & 0.306 & 0.195 & 0.222 & 0.179 \\
\hline 5 & $\begin{array}{lll}\begin{array}{l}\text { Social } \\
\text { group) }\end{array} & \text { Capital(No. of } \\
\end{array}$ & 0.074 & 0.090 & 0.090 & 0.083 & 0.058 & 0.255 & 0.139 & 0.139 & 0.116 \\
\hline 6 & Material Assets possessed & 0.061 & 0.075 & 0.075 & 0.07 & 0.049 & 0.051 & 0.195 & 0.222 & 0.099 \\
\hline 7 & $\begin{array}{l}\text { Technology-diversity } \\
\text { farming methods used }\end{array}$ & 0.053 & 0.064 & 0.064 & 0.06 & 0.042 & 0.044 & 0.028 & 0.222 & 0.072 \\
\hline 8 & $\begin{array}{l}\text { Infrastructure- } \\
\text { roads ,health, education, } \\
\text { transport, electricity, } \\
\text { telephone, security, banks }\end{array}$ & 0.046 & 0.056 & 0.056 & 0.052 & 0.036 & 0.038 & 0.024 & 0.028 & 0.042 \\
\hline & $\begin{array}{l}\text { Last Row average = priority } \\
\text { vector. }\end{array}$ & 1.001 & 0.998 & 0.998 & 1.00 & 1.00 & 1.00 & 0.999 & 1 & 0.998 \\
\hline
\end{tabular}

Table 17 Priority vector for the alternatives

\begin{tabular}{|c|c|c|c|c|c|c|c|c|c|}
\hline & $\mathrm{AC}$ & 1 & 2 & 3 & 4 & 5 & 6 & 7 & 8 \\
\hline 1 & Causal Agent & 0.368 & 0.225 & 0.150 & 0.105 & 0.058 & 0.051 & 0.028 & 0.028 \\
\hline 2 & Capacity to Anticipate & 0.184 & 0.225 & 0.3 & 0.21 & 0.291 & 0.102 & 0.195 & 0.056 \\
\hline 3 & Occupational Mobility & 0.123 & 0.150 & 0.150 & 0.315 & 0.175 & 0.153 & 0.195 & 0.083 \\
\hline 4 & $\begin{array}{l}\text { Occupational Multiplicity(how many } \\
\text { work/employed) }\end{array}$ & 0.092 & 0.113 & 0.113 & 0.105 & 0.291 & 0.306 & 0.195 & 0.222 \\
\hline 5 & Social Capital(No. of group) & 0.074 & 0.090 & 0.090 & 0.083 & 0.058 & 0.255 & 0.139 & 0.139 \\
\hline 6 & Material Assets possessed & 0.061 & 0.075 & 0.075 & 0.07 & 0.049 & 0.051 & 0.195 & 0.222 \\
\hline 7 & $\begin{array}{l}\text { Technology-diversity of farming } \\
\text { methods used }\end{array}$ & 0.053 & 0.064 & 0.064 & 0.06 & 0.042 & 0.044 & 0.028 & 0.222 \\
\hline 8 & $\begin{array}{l}\text { Infrastructure- roads, health, education, } \\
\text { transport, electricity, telephone, } \\
\text { security, banks }\end{array}$ & 0.046 & 0.056 & 0.056 & 0.052 & 0.036 & 0.038 & 0.024 & 0.028 \\
\hline & Columns Total & 1.001 & 0.998 & 0.998 & 1.00 & 1.00 & 1.00 & 0.999 & 1 \\
\hline
\end{tabular}

Step 3 The researcher computed the average of the elements in each row of the normalized matrix. These averages provided an estimate of the relative priorities of the elements being compared. The result was represented as the (relative) priority vector Table 17

Consistency Ratio

The AHP provides a measure of the consistency of pairwise comparison judgments by computing a consistency ratio. The ratio is designed in such a way that values of the ratio exceeding 0.10 are indicative of inconsistent judgments.

How to obtain Consistency Ratio:

Step 1: The researcher multiplied each value in the first column of the pairwise comparison matrix by the relative priority of the first item considered. Same procedures done for other items. The researcher summed the values across the rows to obtain a vector of values labeled "weighted sum." Table 18 below 


\begin{tabular}{|c|c|c|c|c|c|c|c|c|c|c|}
\hline & $\mathrm{AC}$ & 1 & 2 & 3 & 4 & 5 & 6 & 7 & 8 & $\begin{array}{l}\text { Weighted } \\
\text { sum }\end{array}$ \\
\hline 1 & Causal Agent & 0.047 & 0.044 & 0.025 & 0.019 & 0.007 & 0.005 & 0.002 & 0.001 & 0.15 \\
\hline 2 & Capacity to Anticipate & 0.023 & 0.044 & 0.05 & 0.038 & 0.034 & 0.010 & 0.014 & 0.002 & 0.215 \\
\hline 3 & Occupational Mobility & 0.016 & 0.029 & 0.025 & 0.056 & 0.020 & 0.015 & 0.014 & 0.003 & 0.178 \\
\hline 4 & $\begin{array}{l}\text { Occupational } \\
\text { Multiplicity(how many } \\
\text { work/employed) }\end{array}$ & 0.012 & 0.022 & 0.019 & 0.019 & 0.034 & 0.030 & 0.014 & 0.009 & 0.159 \\
\hline 5 & $\begin{array}{l}\text { Social Capital(No. of } \\
\text { group) }\end{array}$ & 0.009 & 0.018 & 0.015 & 0.015 & 0.007 & 0.022 & 0.010 & 0.006 & 0.102 \\
\hline 6 & Material Assets possessed & 0.007 & 0.015 & 0.013 & 0.013 & 0.006 & 0.005 & 0.014 & 0.009 & 0.082 \\
\hline 7 & $\begin{array}{l}\text { Technology-diversity of } \\
\text { farming methods used }\end{array}$ & 0.007 & 0.012 & 0.011 & 0.011 & 0.005 & 0.004 & 0.002 & 0.009 & 0.061 \\
\hline 8 & $\begin{array}{l}\text { Infrastructure- } \\
\text { roads ,health, education, } \\
\text { transport, } \\
\text { telephone, security, banks }\end{array}$ & 0.006 & 0.011 & 0.009 & 0.009 & 0.004 & 0.004 & 0.002 & 0.001 & 0.046 \\
\hline
\end{tabular}

Step 2 Checking consistency- The researcher divided the elements of the vector of weighted sums by the corresponding priority value shown in Table 19.

Table 19 Checking consistency

\begin{tabular}{|l|l|l|l|}
\hline & Weighted sum & Priority Vector & \\
\hline Causal Agent & 0.15 & 0.127 & 1.181 \\
\hline Capacity to Anticipate & 0.215 & 0.195 & 1.103 \\
\hline Occupational Mobility & 0.178 & 0.168 & 1.06 \\
\hline Occupational Multiplicity & 0.159 & 0.179 & 0.888 \\
\hline Social Capital(No. of group) & 0.102 & 0.116 & 0.879 \\
\hline Material Assets possessed & 0.082 & 0.099 & 0.828 \\
\hline Technology-diversity & 0.061 & 0.072 & 0.847 \\
\hline Infrastructure & 0.046 & 0.042 & 1.095 \\
\hline & \multicolumn{3}{|l}{ Row Average } \\
\hline
\end{tabular}

Step 3: The researcher computed the average of the values computed earlier in step $2 \lambda$ max

$\lambda \max =1.181+1.103+1.06+0.888+0.879+0.828+0.847+1.095 / 8$

$$
\begin{aligned}
& =7.881 / 8 \\
& =0.9851
\end{aligned}
$$

Step 4: The researcher computed the consistency index (CI). Where $\mathrm{n}$ is the number of items being compared using the following formula:

$$
\begin{gathered}
\mathrm{CI}=\frac{\lambda_{\max }-\mathrm{n}}{\mathrm{n}-1}=\frac{3.019-3}{3-1}=0.010 \\
\mathrm{CI}=0.9851-8 / 8-1=-7.01149 / 7=-1.00
\end{gathered}
$$

Step 5: The researcher computed the consistency ratio (CR) using formula Saaty, T.L.1980 :

$$
\mathrm{CR}=\frac{\mathrm{CI}}{\mathrm{RI}}
$$

Where RI is the random index, which is the consistency index of a randomly generated pairwise comparison matrix. Random index (RI) is the consistency index of a randomly generated pairwise comparison matrix. RI depends on the number of elements being compared (i.e., size of pairwise comparison matrix) and takes on the following values:

Table 20 Random Index table

\begin{tabular}{|l|l|l|l|l|l|l|l|l|l|l|}
\hline $\mathrm{n}$ & 1 & 2 & 3 & 4 & 5 & 6 & 7 & 8 & 9 & 10 \\
\hline $\mathrm{RI}$ & 0.00 & 0.00 & 0.58 & 0.90 & 1.12 & 1.24 & 1.32 & 1.41 & 1.45 & 1.49 \\
\hline
\end{tabular}

$$
\begin{aligned}
\mathrm{CR} & =-1.00 / 1.41=-0.701 \\
& =-0.701 \leq 0.10
\end{aligned}
$$

The degree of consistency exhibited in the pairwise comparison matrix for indicators of the alternative is acceptable. 


\section{Criteria Matrix for AHP}

Table 21 AHP 9-points scale format ratings for the Criteria

Step 1 Synthensizing judgement

\begin{tabular}{|l|l|l|l|l|l|l|}
\hline & & 1 & 2 & 3 & 4 & 5 \\
\hline 1 & Diversity & 1 & 1 & 1 & 1 & 1 \\
\hline 2 & Human & 0.5 & 1 & 2 & 2 & 2 \\
\hline 3 & Physical & 0.333 & 0.667 & 1 & 3 & 3 \\
\hline 4 & Financial & 0.25 & 0.5 & 0.75 & 1 & 4 \\
\hline 5 & Information & 0.2 & 0.4 & 0.6 & 0.8 & 1 \\
\hline & Column totals & 2.283 & 3.567 & 5.35 & 7.8 & 11 \\
\hline
\end{tabular}

The researcher summed the values in each column of the pairwise comparison matrix.

Column totals (1) 2.283, (2) 3.567, (3) 5.35, (4) 7.8 (5) 11

Step 2

The researcher divided each element of the matrix by its column total.

Table 22 Normalised pairwise comparison matrix for the criteria

\begin{tabular}{|l|l|l|l|l|l|l|}
\hline & & 1 & 2 & 3 & 4 & 5 \\
\hline 1 & Diversity & 0.438 & 0.280 & 0.187 & 0.128 & 0.091 \\
\hline 2 & Human & 0.219 & 0.280 & 0.374 & 0.256 & 0.182 \\
\hline 3 & Physical & 0.146 & 0.187 & 0.187 & 0.385 & 0.273 \\
\hline 4 & Financial & 0.12 & 0.140 & 0.140 & 0.128 & 0.364 \\
\hline 5 & Information & 0.088 & 0.112 & 0.112 & 0.103 & 0.091 \\
\hline & Normalised pairwise & 1.011 & 0.999 & 1.0 & 1.0 & 1.001 \\
\hline
\end{tabular}

All columns in the normalized pairwise comparison matrix now have a sum of 1 . The resulting matrix is now referred to as the normalized pairwise comparison matrix

Step 3 The researcher computed the average of the elements in each row of the normalized matrix. These averages provided an estimate of the relative priorities of the elements being compared. The result was represented as the (relative) priority vector in Table 23.

\begin{tabular}{|l|l|l|l|l|l|l|l|}
\hline \multicolumn{7}{|c|}{ Table 23 priority vector } \\
\hline 1 & Diversity & 1 & 2 & 3 & 4 & 5 & Priority vector \\
\hline 2 & Human & 0.438 & 0.280 & 0.187 & 0.128 & 0.091 & 0.2248 \\
\hline 3 & Physical & 0.219 & 0.280 & 0.374 & 0.256 & 0.182 & 0.2622 \\
\hline 4 & Financial & 0.12 & 0.187 & 0.187 & 0.385 & 0.273 & 0.2356 \\
\hline 5 & Information & 0.088 & 0.112 & 0.140 & 0.128 & 0.364 & 0.1784 \\
\hline & Priority Vector & & & & & & 1.0022 \\
\hline
\end{tabular}

Consistency Ratio- The AHP provides a measure of the consistency of pairwise comparison judgments by computing a consistency ratio. The ratio is designed in such a way that values of the ratio exceeding 0.10 are indicative of inconsistent judgments. How to obtain Consistency Ratio:

Step 1: The researcher multiplied each value in the first column of the pairwise comparison matrix by the relative priority of the first item considered. Same procedures were repeated for other items. The researcher summed the values across the rows to obtain a vector of values labeled "weighted sum." Table 46

Table 24 Weighted Sum of the Criteria matrix

\begin{tabular}{|l|l|l|l|l|l|l|l|}
\hline & & 1 & 2 & 3 & 4 & 5 & Weighted sum \\
\hline 1 & Diversity & 0.098 & 0.073 & 0.044 & 0.023 & 0.009 & 0.247 \\
\hline 2 & Human & 0.049 & 0.073 & 0.088 & 0.046 & 0.018 & 0.274 \\
\hline 3 & Physical & 0.033 & 0.049 & 0.044 & 0.069 & 0.028 & 0.223 \\
\hline 4 & Financial & 0.027 & 0.037 & 0.033 & 0.023 & 0.037 & 0.157 \\
\hline 5 & Information & 0.02 & 0.029 & 0.026 & 0.018 & 0.009 & 0.102 \\
\hline & Weighted sum & & & & & & 1.003 \\
\hline
\end{tabular}


Step 2: The researcher divided the elements of the vector of weighted sums by the corresponding priority value.

Table 25 The highest eigenvector in the matrix

\begin{tabular}{l|l|l|l|}
\hline & Weighted sum & Priority vector & \\
\hline Diversity & 0.247 & 0.2248 & 1.1 \\
\hline Human & 0.274 & 0.2622 & 1.05 \\
\hline Physical & 0.223 & 0.2356 & 0.947 \\
\hline Financial & 0.157 & 0.1784 & 0.880 \\
\hline Information & 0.102 & 0.1012 & 1.007 \\
\hline total & 1.003 & 1.0022 & \\
\hline
\end{tabular}

Step 3: The researcher computed the average of the values computed in step 2 ( $\lambda \max )$.

$$
\begin{array}{r}
\lambda_{\max }=\frac{3.040+3.032+2.985}{3}=3.019 \\
\lambda \max =1.1+1.05+0.947+0.880+1.007 / 5 \\
=4.984 / 5=0.9968
\end{array}
$$

Step 4: The researcher computed the consistency index (CI) using the following formula:

$$
\mathrm{CI}=\frac{\lambda_{\max }-\mathrm{n}}{\mathrm{n}-1}=\frac{3.019-3}{3-1}=0.010
$$

$\mathrm{CI}=0.9968-5 / 5-1=-1.00$

Step 5: The researcher computed the consistency ratio (CR) using the following formula.

$$
\begin{aligned}
\mathrm{CR} & =\frac{\mathrm{CI}}{\mathrm{RI}}=\frac{0.010}{0.58}=0.017 \leq 0.10 \\
\mathrm{CR} & =-1 / 1.12 \\
& =-0.893 \\
& -0.893 \leq 0.10
\end{aligned}
$$

The degree of consistency exhibited in the pairwise comparison matrix for indicators of the criteria for the goal is acceptable.

Development of Priority Ranking

The overall priority for each decision alternative is obtained by summing the product of the criterion priority (i.e., weight) (with respect to the overall goal) times the priority (i.e., preference) of the decision alternative with respect to that criterion. To rank the priority values, the researcher had AHP ranking of the decision alternatives first.

Step 1: From the pairwise comparison matrices the researcher prepared for both Alternatives and Criteria to go to Priority Ranking analysis

Step 2: The researcher calculated priority vector for each matrix (from all the matrixes)

Priority Ranking Proper

Step 1: The researcher summed the product of the criterion priority (with respect to the overall goal) times the priority of the decision alternative with respect to that criterion Table 26.

Table 26 Summing the product of criterion times priority of decision alternative

\begin{tabular}{l|l|l|l|l|}
\hline & Priority vector Alternative & Priority vector criterion & Priority Ranking & \\
\hline Causal Agent & 0.127 & 0.2248 & 0.224 & \\
\hline Anticipation & 0.195 & 0.2622 & 0.261 & The Winner \\
\hline Mobility & 0.168 & 0.2356 & 0.232 & \\
\hline Multiplicity & 0.179 & 0.1784 & 0.178 & \\
\hline Social Capital & 0.116 & 0.1012 & 0.099 & \\
\hline Material Assets & 0.099 & & & \\
\hline Technology & 0.072 & & & \\
\hline Infrastructure & 0.042 & & & \\
\hline
\end{tabular}

Step 2: The researcher ranked the priority values as below.

1. $029+0.044+0.038+0.040+0.026+0.022+0.016+0.009=0.224$

2. $0.033+0.051+0.044+0.047+0.030+0.026+0.019+0.011=0.261$ - The winner is Capacity to Anticipate Change

3. $0.029+0.046+0.039+0.042+0.027+0.023+0.017+0.009=0.232$

4. $0.023+0.035+0.029+0.032+0.021+0.018+0.013+0.007=0.178$

5. $0.013+0.019+0.017+0.018+0.011+0.010+0.007+0.004=0.099$

\subsection{4}

The researcher computed weights using the Analytical Network Process (ANP) software, Super Decisions version 3.0. The calculation of priorities adopted the procedure of Beritella et al. (2007) which converts the responses of 
key informants into a judgmental matrix:

$$
A=\left[\begin{array}{cccc}
a_{11} & a_{12} & \ldots & a_{1 n} \\
a_{21} & a_{22} & \ldots & a_{2 n} \\
\ldots & \ldots & \ldots & \ldots \\
a_{n 1} & a_{n 2} & \ldots & a_{n n}
\end{array}\right]
$$

Where:

aij = the key informant's comparison rating between element $\mathrm{i}$ and

element $\mathrm{j}$ of a given level with respect to the upper level of the hierarchy with

$$
a_{i j}>0 ; a_{i j}=\frac{1}{a_{j i}} ; a_{i i}=1 \text { for all } i \text {. }
$$

The priorities or weights of the elements were estimated by finding the principal eigenvector w of the matrix A which is: $\mathrm{AW}=\lambda \max \mathrm{W}, \lambda \max$ is the largest eigenvector of the matrix $\mathrm{A}$. The vector $\mathrm{W}$ is normalized to get the vector of priorities of elements of one level with respect to the upper level. The priorities serve as weights of the elements at each hierarchic level.

Figure 10 shows the results from the panel of fifteen key informants (drawn from the line ministries, involved in this area), purposively chosen, to provide ratings on the relative importance of the different indicators of adaptive capacity. The ratings were elicited using the pairwise comparison questionnaire, which comes with the method of Analytic Hierarchy Process

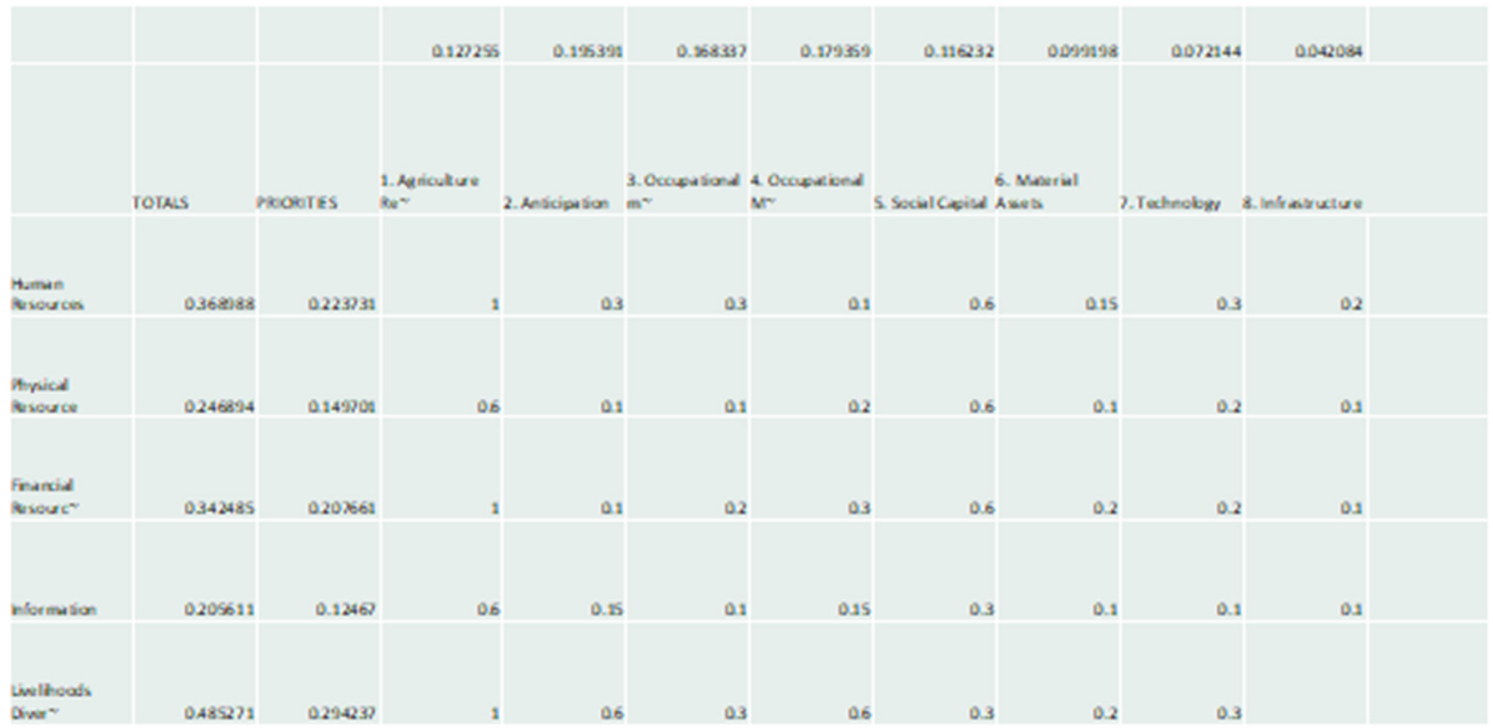

Figure 10 priorities from the super decision software

Using the Analytic Hierarchy Process (AHP) the results are presented in figure 11 which shows the overall synthesized priorities for the Criterion. This figure indicates that Livelihoods Diversity has the highest score at 0.299886 which to the two decimal points is 0.3 . When the Number of livelihoods sources or sources of income are many and when the number of members in the household are also having different sources of income or livelihoods, then that household has a high adaptive capacity. The panel of key informants gave this alternative the highest weight and so this is the single adaptive capacity for Kinakomba ward. Livelihoods diversity also includes the number of crops that the households planted in a year and the different kinds of crops ranging from tubers, cereals, vegetables and fruits. The Analytic Hierarchy Process (AHP) provides a logical framework to determine the benefits of each alternative. Thus the highest score is 0.3 while the lowest for Criterion is information at 0.123311 as shown in Figure 11 below. 


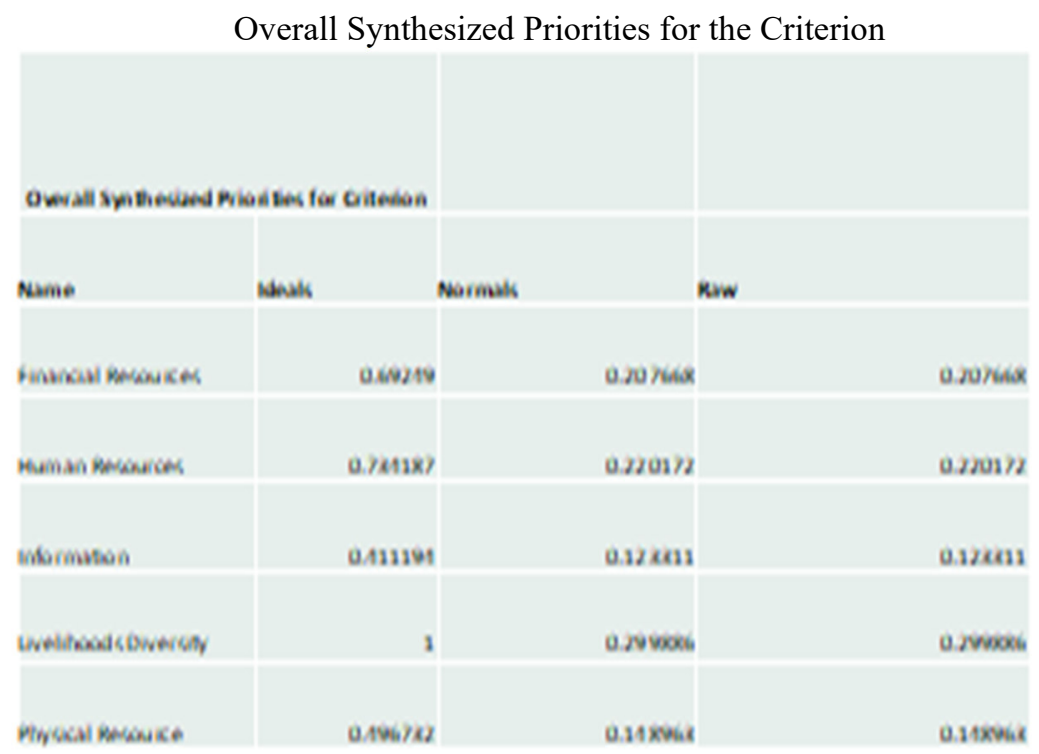

Figure 11 Overall synthesized priorities for Criterion

Then figure 12 presents the Column priorities from the Ratings. From this figure occupational multiplicity has the highest score at 0.206312 . This means the total number of person-jobs in the household. If all the members of the households are adults and each has a job then the adaptive capacity of that household is high. It is different from when a household has adult members who are jobless and are depending on one member of the household. Also if the household members are adults and are incapacitated from working and only one adult is taking care of the rest this creates a high dependence rate making that household to have a low adaptive capacity. It is the same when one adult is working and the rest of the household members who may be children are not working but depending on him or her. The panel of the key informants gave this indicator a high rating thus making it have the highest adaptive capacity while the lowest was given to infrastructure at 0.033848 as shown in Figure 12 below:

Column Priorities from the Ratings

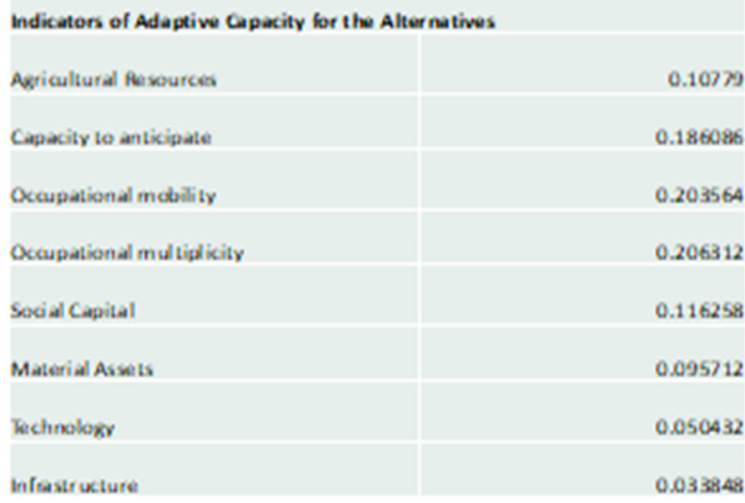

Figure 12 Column priorities from the ratings for Alternatives

3.3 Testing for Hypothesis (Lehmann et al. 2005)

The chi-square goodness of fit test is applied when there is one categorical variable from a single population. It is used to determine whether sample data are consistent with a hypothesized distribution.

It is appropriate to use the chi-square goodness of fit test when, the sampling method is simple random sampling, the variable under study is categorical and the expected value of the number of sample observations in each level of the variable is at least 5. There are 4 steps: State the hypotheses, Formulate an analysis plan, Analyze sample data, and then interpret results.

Step 1: State the Hypotheses

Every hypothesis test requires the researcher to state a null hypothesis $\left(\mathrm{H}_{0}\right)$ and an alternative hypothesis $\left(\mathrm{H}_{\mathrm{a}}\right)$. The hypotheses are stated in such a way that they are mutually exclusive. That is, if one is true, the other must be false; and vice versa.

i. $\mathrm{H}_{01}$ The adaptive capacity of the smallholder farmers in Kinakomba Ward is Not significantly related to the ownership and access to resources, information and technology, and ability to diversify livelihoods to cope with Climate-related stresses 
ii. $\mathrm{H}_{\mathrm{a} 1}$ : The adaptive capacity of the smallholder farmers in Kinakomba Ward is significantly related to the ownership and access to resources, information and technology, and ability to diversify livelihoods to cope with Climate-related stresses.

Step 2: Formulate an Analysis Plan

This analysis plan describes how to use sample data to accept or reject the null hypothesis. Note that for the null hypothesis to be rejected at least one of the specified proportions is not true.

1.Significance Level here is equal to 0.05

2.The test Method. The researcher used the Chi-square goodness of fit test to determine whether observed sample frequencies differed significantly from expected frequencies specified in the null hypothesis.

Step 3: Analyze Sample Data

Using sample data the researcher looked for the degrees of freedom, expected frequency counts, test statistic, and the P-value associated with the test statistic.

Degrees of Freedom (DF) is equal to the number of levels (k) of the categorical variable minus 1 in Kinakomba case it was the number of the Criterion which were five:

$\mathrm{DF}=\mathrm{k}-1$. In this case it is $5-1=4$

The expected frequency counts at each level of the categorical variable are equal to the sample size times the hypothesized proportion from the null hypothesis.

$\mathrm{E}_{\mathrm{i}}=\mathrm{np}_{\mathrm{i}}$

Where $E_{i}$ is the expected frequency count for the ith level of the categorical variable, $n$ is the total sample size, and $\mathrm{p}_{\mathrm{i}}$ is the hypothesized proportion of observations in level i. In this Study:

$\mathrm{E}_{1}=390 * 0.294(114.66) \quad \mathrm{E}_{2}=390 * 0.125(48.75) \quad \mathrm{E}_{3}=390 * 0.208(81.12) \quad \mathrm{E}_{4}=390 * 0.150(58.5) \quad \mathrm{E}_{5}=390 * 0.224(87.36)$

The test statistic is a chi-square random variable $\left(\mathrm{X}^{2}\right)$ defined by the following equation:

$\mathrm{X}^{2}=\Sigma\left[\left(\mathrm{O}_{\mathrm{i}}-\mathrm{E}_{\mathrm{i}}\right)^{2} / \mathrm{E}_{\mathrm{i}}\right]$

Where $\mathrm{O}_{\mathrm{i}}$ is the observed frequency count for the ith level of the categorical variable, and $\mathrm{E}_{\mathrm{i}}$ is the expected frequency count for the ith level of the categorical variable.

$\mathrm{X}^{2}=\Sigma\left[\left(\mathrm{O}_{\mathrm{i}}-\mathrm{E}_{\mathrm{i}}\right)^{2} / \mathrm{E}_{\mathrm{i}}\right]$

$\mathrm{X}^{2}=\left[(114-114.66)^{2} / 114.66\right]+\left[(48-48.75)^{2} / 48.75\right]+\left[(81-81.12)^{2} / 81.12\right]+\left[(58-58.5)^{2} / 58.5\right]+\left[(87-87.36)^{2} / 87.36\right]$

$\mathrm{X}^{2}=\left[(-0.66)^{2 / 114.66]}+\left[(-0.75)^{2 / 48.75]}+\left[(-0.12)^{2 / 81.12}\right]+\left[(-0.5)^{2} / 58.5\right]+\left[(-0.36)^{2 / 87.36}\right]\right.\right.$

$=0.00379+0.01153+1.7751+0.00427+0.00148=1.7962$

where DF is the degrees of freedom, $\mathrm{k}$ is the number of levels of the categorical variable, $\mathrm{n}$ is the number of observations in the sample, $\mathrm{E}_{\mathrm{i}}$ is the expected frequency count for level $\mathrm{i}, \mathrm{O}_{\mathrm{i}}$ is the observed frequency count for level $\mathrm{i}$, and $\mathrm{X}^{2}$ is the chi-square test statistic.

The P-value is the probability that a chi-square statistic having 4 degrees of freedom is more extreme than 0.9997. Using the Chi-square Distribution Calculator to find $\mathrm{P}\left(\mathrm{X}^{2}>0.9997\right)=1.7962$.

Step 4: Interpret Results

Since the P-value (1.7962) is more than the significance level (0.05), the researcher accepts the null hypothesis. This approach is appropriate because the sampling method was simple random sampling, the variable under study was categorical, and each level of the categorical variable had an expected frequency count of at least 5

\section{Conclusion}

Using the Analytic Hierarchy Process (AHP) the results are presented in figure 11 which shows the overall synthesized priorities for the Criterion. This figure indicates that Livelihoods Diversity has the highest score at 0.299886 which to the two decimal points is 0.3 . When the Number of livelihoods sources or sources of income are many and when the number of members in the household are also having different sources of income or livelihoods, then that household has a high adaptive capacity. The panel of key informants gave this alternative the highest weight and so this is the single adaptive capacity for Kinakomba ward. Livelihoods diversity also includes the number of crops that the households planted in a year and the different kinds of crops ranging from tubers, cereals, vegetables and fruits. The Analytic Hierarchy Process (AHP) provides a logical framework to determine the benefits of each alternative. Thus the highest score is 0.3 while the lowest for Criterion is information at 0.123311 .

Then from the Ratings occupational multiplicity has the highest score at 0.206312 . This means the total number of person-jobs in the household. If all the members of the households are adults and each has a job then the adaptive capacity of that household is high. It is different from when a household has adult members who are jobless and are depending on one member of the household. Also if the household members are adults and are incapacitated from working and only one adult is taking care of the rest this creates a high dependence rate making that household to have a low adaptive capacity. It is the same when one adult is working and the rest of the household members who may be children are not working but depending on him or her. The panel of the key informants gave this indicator a high rating thus making it have the highest adaptive capacity while the lowest was given to infrastructure at 0.033848 . 


\section{Recommendations}

i. That the County and National Government involve the smallholder farmers through participatory approaches in assessing their adaptive capacities to arrive at appropriate adaptation actions.

ii. That the smallholder farmers be given the role of defining their adaptation goals so that the measures taken by stakeholders are relevant and linking capacity and actions taken.

iii. The smallholder farmers should make their rules and procedures of adapting to the measures they take so that they can enforce them for their own survival while stakeholders empower them through knowledge and financial resources to reach the adaptation goals they aspire and design.

iv. The stakeholders to build the capacity of the smallholder farmers on the climate risks which are characterized by uncertainty, ambiguity and unpredictability so that they can cope in the eventuality of hazards leading to disasters.

v. Early warnings from the government multi-agency are key to smallholder farmers so that they can be in a state of preparedness when immanent disasters from climate variabilities are inevitable.

vi. Adaptation measures need to be in the contingency plans of both the County and National governments agenda throughout the year because of the unpredictability of the weather patterns in Kenya.

\section{References}

Adger, W. N., N. Brooks, G. Bentham, M. Agnew, and S. Eriksen. 2004. New indicators of vulnerability and Adaptive capacity. Tyndall Centre Technical Report 7. Tyndall Centre for Climate Change Research, Norwich, UK. [Online] URL: http://www.tyndall.ac.uk/content/new-indicators-vulnerability-and-Adaptive capacity.

Adger, W. N., Arnell, N. W. and Tompkins, E. L. (2005a) Successful Adaptation to Climate Change across Scales, Global Environmental Change, 15, 77-86.

Adger, W. N., K. Brown, D. R. Nelson, F. Berkes, H. Eakin, C. Folke, K. Galvin, L. Gunderson, M. Goulden, K. O’Brien, J. Ruitenbeek, and E. L. Tompkins. 2011b. Resilience implications of policy responses to Climate change. Wiley Interdisciplinary Reviews: Climate Change 2(5):757-766. http://dx.doi.org/10.1002/ wcc.133

Armitage, D., (2007) Building resilient livelihoods through adaptive co-management: the role of Adaptive capacity, in: Armitage, D., Berkes, F., Doubleday, N.C. (Eds.), Adaptive Co management: Collaboration, Learning and Multi-level Governance. UBC Press, Vancouver, pp. 62-82.

Basurto, X., Gelcich, S, Ostrom, E., (2013). The social-ecological system framework as a Knowledge classificatory system for benthic small-scale fisheries. Global Environ. Change (2013), http://dx.doi.org/10.1016/j.gloenvcha.2013.08.001

Berrittella, M., A Certa, M. Enea, P. Zito., (2007). An Analytic Hierarchy Process for the Evaluation of Transport Policies to Reduce Climate Change Impacts. Fondazione ENI Enrico Mattei (FEEM) working paper 12.2007.

Birkmann, J. (2013) 'Measuring vulnerability to promote disaster-resilient societies: conceptual frameworks and Definitions', in Birkmann, J. (Ed.): Measuring Vulnerability to Natural. Hazards: Towards Disaster Resilient Societies, 2nd ed., pp.9-80, United Nations University, New York.

Birkmann, J., Buckle, P., Jaeger, J., Pelling, M., Setiadi, N., Garschagen, M., Fernando, N. and Kropp, J. (2010) 'Extreme events and disasters: a window of opportunity for change? Analysis of organizational, Institutional and political changes, formal and informal responses after mega-disasters', Natural Hazards, Vol. 55, No. 3, pp.637-669.

Birkmann, J., Cutter, S., Rothman, D., Welle, T., Garschagen, M., van Ruijven, B., O`Neill, B., Prestion, B.L., Kienberger, S., Cardona, O.C., Siagin, T., Hidayati, D., Stetiadi, N., Binder, C., Hughes, B. And Pulwarty, R. (2013) 'Scenarios for vulnerability: opportunities and constraints in the context of climate Change and disaster risk', Climatic Change, DOI 10.1007/s10584-013-0913-2 [online] http://link.springer.com/article/10.1007/s10584-013-0913-2 (accessed 23 August 2013).

Birkmann, J., Welle, T., Krause, D., Wolfertz, J., Suarez, D.C. and Setiadi, N. (2011) WorldRiskIndex: Concept and Results, WeltRisikoBericht (Ed.), pp.S.13-43, Bündnis Entwicklung Hilft, Berlin

Cox, M., 2011. Advancing the diagnostic analysis of environmental problems. International Journal of the Commons 5, 346-363.

Cronbach LJ (1951). "Coefficient alpha and the internal structure of tests". Psychometrika 16 (3): $297-334$.

Department for International Development. 1999. Sustainable Livelihoods Guidance Sheets. London.

Eakin, H., and L. A. Bojorquez-Tapia. 2008. Insights into the Composition of Household Vulnerability from Multicriteria Decision Analysis. Global Environmental Change 18: 112-127

Eakin, H. C., and M. B. Wehbe. 2009. Linking local vulnerability to system sustainability in a resilience Framework: two cases from Latin America. Climatic Change 93(3-4):355-377. http://dx.doi. 
org/10.1007/s10584-008-9514-x

Foxton, T. J. (2007) Technological Lock-in and the Role of Innovation, in Atkinson, G., Dietz, S. and Neumayer,

E. (eds.) Handbook of Sustainable Development, Cheltenham: Edward Elgar.

Harvey, D., (2010) The Enigma of Capital, London: Profile Books.

Hedström, Peter, and Petri Ylikoski., (2010). Causal Mechanisms in the Social Sciences. Annual Review of Sociology 36 (1): 49-67.

Hulme, M., (2009) Why We Disagree About Climate Change, Cambridge: Cambridge University Press.

Intergovernmental Panel on Climate Change. 2001. Climate Change 2001: Impacts, Adaptation and Vulnerability. A Contribution of the Working Group II to the Third Assessment Report of the Intergovernmental Panel on Climate Change Edited. by McCarthy, J.J., O.F.Canziani, N.A. Leary, D.J. Dokken, and K.S. White. Cambridge: Cambridge University Press.

IPCC Climate Change, (2007): Impacts, Adaptation and Vulnerability (eds Parry M. L., Canziani, O. F., Palutikof, J. P., van der Linden, P. J. \& Hanson, C. E) (Cambridge Univ. Press, 2007).

IPCC (2014). "Glossary" (PDF). Intergovernmental Panel on Climate Change

ISDR, (2004) Living with Risk: A Global Review of Disaster Reduction Initiatives, Volume II, Geneva: ISDR.

Keskitalo, E. C. H., H. Dannevig, G. K. Hovelsrud, J. J. West, and Å. G. Swartling. 2011. Adaptive capacity determinants in developed states: examples from the Nordic countries and Russia. Regional Environmental Change 11(3):579-592. http://dx.doi. org/10.1007/s10113-010-0182-9

Kothari C. R., (2004), Research Methodology, Methods and Techniques, Second Revised Edition 2004, New Age International (P) Ltd., Publishers, India at Dharmes Printers, Delhi.

Lavell, A., Oppenheimer, M., Diop, C., Hess, J., Lempert, R., Li, J., Muir-Wood, R. and Myeong, S. (2012) 'Climate change: new dimensions in disaster risk, exposure, vulnerability, and resilience', in Field, C.B., Barros, V., Stocker, T.F., Qin, D., Dokken, D.J., Ebi, K.L., Mastrandrea, M.D., Mach, K.J., Plattner, G-K., Allen, S.K., Tignor, M. and Midgley, P.M. (Eds.): Managing the Risks of Extreme Events and Disasters to Advance Climate Change Adaptation, A Special Report of Working Groups I and II of the Intergovernmental Panel on Climate Change (IPCC), pp.25-64, Cambridge University Press, Cambridge, UK, and New York, NY, USA.

Lehmann, E. L.; Romano, Joseph P. (2005). Testing Statistical Hypotheses (3E ed.). New York: Springer. ISBN 978-0-387-98864-1

Mark Pelling, (2011), Adaptation to Climate change: from Resilience to Transformation Routledge 2 Park Square, Milton Park, Abingdon, Oxon, OX14 4RN simultaneously published in the USA and Canada by Routledge, 270 Madison Avenue, New York, NY 10016 Routledge is an imprint of the Taylor \& Francis Group, an informa business

Marshall, N. A., S. E. Park, W. N. Adger, K. Brown, and S. M. Howden. 2012. Transformational capacity and the influence of place and identity. Environmental Research Letters 7(3):1-9. http://dx.doi.org/10.1088/17489326/7/3/034022

Marshall, N. A., S. E. Park, W. N. Adger, K. Brown, and S. M. Howden. 2012. Transformational capacity and the influence of place and identity. Environmental Research Letters 7(3):1-9. http:// dx.doi.org/10.1088/17489326/7/3/034022

McGinnis, M. D., (2011). Networks of adjacent action situations in polycentric governance. Policy Studies Journal 39(1):51-78.

Moss R. H, Malone EL, Brenkert AL (2001) Vulnerability to climate change: a quantitative approach, Joint Global Change Research Institute. PNNL-SA-33642. Pacific Northwest National Laboratory, Washington

Ostrom, E. (2005). Understanding institutional diversity. Princeton University Press, Princeton, New Jersey, USA.

Ostrom E. (2007).A diagnostic approach for going beyond panaceas. Proceedings of the National Academy of Sciences 104 (39):15181-15187. http://dx.doi.org/10.1073/pnas.0702288104

Ostrom, E. (2009). A general framework for analyzing sustainability of social-ecological Systems. Science, $325(5939), 419-422$

Ostrom, E. (2010). Beyond markets and states: polycentric governance of complex economic Systems. American Economic Review 100(3):641-672. http://dx.doi.org/10.1257/aer.100.3.641

Ostrom, E., and M. Cox. (2010). Moving beyond panaceas: a multitiered diagnostic approach for Social-ecological analysis. Environmental Conservation 37(4):451-463. http://dx.doi.org/10.1017/ S0376892910000834

Ostrom, E. (2013). Do institutions for collective action evolve? Journal of Bioeconomics: 1-28

Saaty, T. 1994. Fundamentals of Decision Making and Priority Theory with Analytic Hierarchy Process. RWS Publications, Pittsburgh, USA.

Saaty T. L., 1980. The analytic hierarchy process: planning, priority setting and resource allocation. McGraw-Hill, New York

Shadish, William R, Thomas D Cook, and Donald Thomas Campbell. (2002). Experimental and Quasi experimental designs for generalized causal inference. Wadsworth Cengage learning. 
Smit, B., I. Burton, R. J. T. Klein, and J. Wandel. 2000. An anatomy of adaptation to climate change and Variability. Climatic Change 45(1):223-251. http://dx.doi.org/10.1023/A:1005661622966

Smit, B., and J. Wandel. 2006. Adaptation, adaptive capacity and vulnerability. Global Environmental Change 16(3):282-292. http:// dx.doi.org/10.1016/j.gloenvcha.2006.03.008

TEEB (2010b). The economics of ecosystems and biodiversity: mainstreaming the economics of nature: a synthesis of the approach, conclusions and recommendations of TEEB. TEEB, October 2010.

UKCIP (2003). Climate change and local communities - How prepared are you? An adaptation guide for local Authorities in the UK, United Kingdom Climate Impacts Programme. Available at: http://www.ukcip.org.uk/ resources/publications/documents/Local authority.pdf

UNDP/GEF (2003). Capacity Development Indicators, New York, US.

UNDP/GEF (2004). Assessing Technology Needs to Address Climate Change, New York, US. Available at: http://www.undp.org/cc/technology.htm

Vincent, K. 2007. Uncertainty in adaptive capacity and the importance of scale. Global Environmental Change 17(1):12-24. http://dx.doi.org/10.1016/j.gloenvcha.2006.11.009

Yohe G, Tol RSJ (2002) Indicators for social and economic coping capacity-moving toward a working Definition of adaptive capacity. Glob Environ Chang 12:25-40

Young, O.R., King, L.A., Schroeder, H., (2008). Building regimes for socioecological systems: Institutional diagnostics. In: Young, O.R., King, L.A., Schroeder, H. (Eds.), Institutions and Environmental Change: Principal Findings, Applications, and Research Frontiers. MIT Press, Cambridge, MA. 